\title{
Negotiating Liminality in Higher \\ Education: Formal and Informal \\ Dimensions of the Student Experience \\ as Facilitators of Quality
}

\author{
Vanessa Rutherford and Ian Pickup
}

\section{Introduction and Institutional Background}

A belief in the importance of higher education in the new knowledge society has led to a massification of higher education globally (Loukkola and Zhang 2010) and an associated rise of professional administration and management processes. These include an increase in demand for quality assurance (QA) processes, such as those contained within the European Standards and Guidelines (European Association for Quality Assurance in Higher Education 2009). Concurrently, the student population across Europe is becoming increasingly diverse (Finnegan et al. 2014) creating a key challenge for higher education institutions: how best to serve the twin aim of supporting all students to succeed, whilst fostering a high quality and inclusive higher education experience.

In this paper, we examine research that feeds into policy making at University College Cork, Ireland (UCC). We examine micro level human experiences and interactions that impact learning. We are less concerned with compliance, assessment regulations, reporting and performance indicators. Rather, we focus on the research into solutions and innovations in learning and student development. The University has placed a high priority on developing comprehensive programmes and structures to support student transition and success. Active student participation in the full breadth of student life is a key component of the 'aspired to' high quality experience at $\mathrm{UCC}$.

UCC was established in 1845. There are currently approximately 18,000 full-time students-14,000 follow undergraduate programmes, while 4,000 are

\footnotetext{
V. Rutherford $(\bowtie) \cdot$ I. Pickup

National University of Ireland, Cork, Ireland

e-mail: v.rutherford@ucc.ie

I. Pickup

e-mail: i.pickup@ucc.ie

(C) The Author(s) 2015

A. Curaj et al. (eds.), The European Higher Education Area,

DOI 10.1007/978-3-319-20877-0_44
} 
engaged in postgraduate study and research. The student body includes 3000 international students presenting 100-plus countries worldwide. The University's Centre for Adult Continuing Education serves an additional 2200 part-time students. The 165-year history of UCC is 'hallmarked by an ethos of excellence' (UCC Strategic Plan 2013-2017, p. 6).

UCC developed a Strategic Plan (2013-2017) through extensive consultation with students, staff, alumni, external agencies and other key stakeholders. The Strategic Plan is aligned with the 'objects' of the University under the Universities Act, 1997 and it is informed by international trends, national policy and by the University's quality improvement and risk management processes. The key strategic mission at UCC: "inspires creativity and independent thinking in a research-led teaching and learning environment. Our students are our highest priority. Through our research excellence we create and communicate knowledge to enhance the intellectual, social, cultural and economic life regionally, nationally and internationally" (UCC Strategic Plan 2013-2017: 13).

Strategic planning at UCC emphasises the development and implementation of organization-wide accountability, leadership, excellence and collaboration in the name of quality. The Strategic Plan acknowledges the day-to-day importance of the student experience. Students are perceived as key stakeholders within the institution. They are identified in the exchange process and there is cognisance that meaningful relationships ultimately provide positive results for all stakeholders. There is an explicit institutional commitment to:

Sustain the current high satisfaction levels in the “...student experience by delivering strong student focused support services and activities which address the physical, psychological, spiritual, social, and cultural and welfare needs of students and by embedding a regular review of the student feedback process to ensure that recommendations for quality improvement are implemented ...." (UCC, Strategic Plan 2013-2017).

The manifestation of espoused strategy at UCC is evidenced through significant initiatives that offer students supplementary admission routes and a variety of academic, personal and social services while studying at third level. These include the National Disability Access Route to Education (DARE) ${ }^{1}$ and The National Higher Education Access Route (HEAR). ${ }^{2}$ Both DARE and HEAR offer reduced points places, whilst some students applying through these national systems are also afforded places on merit. ${ }^{3}$ The Strategic Plan (2013-2017) emphasises the commitment to enhancing accessibility for all students and widening participation

\footnotetext{
${ }^{1}$ DARE is a college and university admissions scheme that may offer places on reduced points to school leavers with disabilities.

${ }^{2}$ The Higher Education Access Route (HEAR) is a college and university admissions scheme which may offer places on reduced points and extra college support to school leavers from socio-economically disadvantaged backgrounds.

${ }^{3}$ In Ireland applicants are ranked in order of merit of performance at school leaving examinations and this is called the points system. Each applicant's score is calculated by allocating points for grades achieved in one sitting of the Leaving Certificate examination.
} 
through an inclusive environment that embraces diversity and equality. The focus on equity of access to higher education is a macro national priority and has been clearly articulated as such in the Irish Department of Education and Skills Higher Education System Performance Framework (2014)-(2016). This Performance Framework also sets out a range of high level system indicators to assess and measure the higher education system's performance in this priority area (Higher Education Authority 2014). The proposed vision for the future of higher education in Ireland is clearly set out in a recent consultation document:

Over the period of this National Access Plan (2014-2017), in partnership with other stakeholders, Irish higher education will become a more fully inclusive system that enables more citizens, irrespective of age, socioeconomic background, disability or other factors to access in, participate in, and complete higher education and achieve their full potential, as part of the overall social and economic development of Irish society. Access to higher education will be intrinsic to what a higher education institution does, interlinked with teaching and learning, research and civic engagement (HEA 2014).

At UCC, strategies are formulated amid dense interplay between macro global and national challenges, an individual strategic agenda and organisational identity and history (Kegan 1994, p. 34). The strategy-as-practice approach which emphasises practical, everyday student life actively shapes UCC's university plan and seeks to understand and address stakeholder demands. Cultivating this 'stakeholder friendly culture' (Leap and Loughry 2004) offers the potential to construct positive experiences and smooth transitions.

This paper explores liminality in the higher education student experience and the ways in which student experience theory has the potential to further advance into policy and practice at an institutional level, facilitating improved student empowerment in learning. In this paper, we focus on epistemological and ontological shifts in identity and relationships over the course of a student's university journey. Student identities are thought to evolve, as participation and engagement in higher education are experienced over time (Wortham 2006). Student experience incorporates critical thinking, independent learning, fossilization of identity, development of relationships, valuing of diversity and inclusion, consideration of multiple perspectives and collaboration. We see a need to establish and further develop innovative support structures, and equip students with 'threshold capital' that helps them to negotiate challenging and sometimes troublesome learning and development situations, to open up and move along the spectrum of liminality - to transition their learning (Land 2012). 


\section{Student Experience and the European Context-A Literature Review}

Literature concerning the student experience is varied and rich. We summarise the key findings of our literature review in Table 1 . We identified high level themes and sub themes of the student experience drawn from the literature .

The vast literature exposes specific aspects of the student experience, yet the threshold concept approach and liminality remain underdeveloped in understanding the holistic higher education student experience. The Threshold Concepts (TC) framework was developed by Meyer and Land (2003) and has features that are transformative, irreversible, integrative, bounded, potentially troublesome, discursive and reconstitutive. It emphasises acquisition of knowledge. Liminality is identified as a core TC and refers to the period or space of transformation that students undergo or are challenged by. Liminality is the transition from old to new being and understanding (Meyer and Land 2005). The British Cultural Anthropologist, Victor Turner (1920-1983) defined liminality as the in-between time and place in the process of transformation (Turner 1969). Such ways of framing specific aspects of the student experience emphasise the epistemological and leave little room for the study of complex and often invisible social and cultural phenomena, such as events and actions, over time. Our research deals specifically with a threshold concept approach in the broader sense, coupled with liminality, and we explore the processes and implications, the enactment, the performance, and the doing that are not discipline specific, but which characterize every student's experiences. It sheds light on the need for further partnership and meaningful collaboration between all stakeholders. A better understanding of the student experience offers the potential to contribute to the development of methods used to support the student experience by aligning theory with the lived student experience and the practice of university staff.

\section{The Student, 'Threshold Concepts' and Liminality}

In this paper, we specifically reflect on how students navigate today's complex world of higher education, and use 'threshold concepts' as a lens for analysis (Meyer and Land 2003). Student-hood, we argue, is a specific and provisional identity. Students are assigned official status as university students once they fulfil institutional and programme requirements. Often, the most significant parts of student-hood lie in imagined becomings and measured outcomes such as exam results, certificate, degree, graduation and career. As one student noted in our study, the most significant outcome was perceived as 'being able to get my degree in a well recognised establishment' (Second year female undergraduate student 2013). Here, we focus on the processes, and periods of greatest personal and academic 
Table 1 Select literature review

\begin{tabular}{|c|c|c|}
\hline High level themes & Sub themes & Select references \\
\hline \multirow[t]{2}{*}{ Bologna Process mobility } & Student experience & $\begin{array}{l}\text { Altbach }(2002,2004, \\
\text { 2007) }\end{array}$ \\
\hline & Student qualifications & $\begin{array}{l}\text { Bekhradnia et al. } \\
\text { (2006) }\end{array}$ \\
\hline \multirow[t]{2}{*}{ Student experience } & Academic ability & Booth (2009) \\
\hline & Overall judgement & $\begin{array}{l}\text { Bordonaro and } \\
\text { Richardson (2004) }\end{array}$ \\
\hline \multirow{2}{*}{$\begin{array}{l}\text { Institutional commitment to } \\
\text { student learning }\end{array}$} & \multirow[t]{2}{*}{ Student aspirations/expectations } & Bent (2008) \\
\hline & & $\begin{array}{l}\text { Biggs and Tang } \\
\text { (2011) }\end{array}$ \\
\hline \multirow[t]{2}{*}{ Student engagement } & \multirow[t]{2}{*}{ Adjustments: school-university } & $\begin{array}{l}\text { Brinkworth et al. } \\
\text { (2009) }\end{array}$ \\
\hline & & Christie et al. (2008) \\
\hline \multirow[t]{2}{*}{ Widening participation } & \multirow[t]{2}{*}{ Academic adjustments } & $\begin{array}{l}\text { Cook and Leckey } \\
(1999)\end{array}$ \\
\hline & & Colvin (2007) \\
\hline Student transition & Academic orientation & $\begin{array}{l}\text { Roberts and Tyler } \\
(2007)\end{array}$ \\
\hline \multirow[t]{2}{*}{ 'Learning to learn' } & Academic application & Harvey et al. (2006) \\
\hline & Student engagement with learning & Huet et al. (2009) \\
\hline Students' critical engagement & $\begin{array}{l}\text { Identified need for early support } \\
\text { from universities' }\end{array}$ & Hultberg et al. (2008) \\
\hline $\begin{array}{l}\text { Becoming 'co producers of } \\
\text { meaning' }\end{array}$ & Intellectual stimulation & $\begin{array}{l}\text { Hussey and Smith } \\
\text { (2010) }\end{array}$ \\
\hline $\begin{array}{l}\text { Scaffolding students into } \\
\text { autonomous learning }\end{array}$ & Sense of belonging & Kember (2001) \\
\hline $\begin{array}{l}\text { University proactive } \\
\text { management }\end{array}$ & Student departure & Leese (2010) \\
\hline $\begin{array}{l}\text { Treatment of curriculum as an } \\
\text { academic milieu }\end{array}$ & $\begin{array}{l}\text { Student satisfaction with teaching, } \\
\text { learning and course }\end{array}$ & $\begin{array}{l}\text { Lumsden et al. } \\
\text { (2010) }\end{array}$ \\
\hline \multirow{2}{*}{$\begin{array}{l}\text { First year experience and } \\
\text { retention }\end{array}$} & Feedback & Mayhew et al. (2010) \\
\hline & Peers and peer mentoring & Reason et al. (2006) \\
\hline \multirow[t]{2}{*}{$\begin{array}{l}\text { Student success and methods } \\
\text { of learning }\end{array}$} & ICT, library resources & $\begin{array}{l}\text { Bordonaro and } \\
\text { Richardson (2004) }\end{array}$ \\
\hline & Gender & $\begin{array}{l}\text { Rivza and Teichler } \\
\text { (2007) }\end{array}$ \\
\hline University resources & \multirow[t]{2}{*}{ Social class } & Storrs et al. (2008) \\
\hline $\begin{array}{l}\text { University monitoring of } \\
\text { achievement }\end{array}$ & & $\begin{array}{l}\text { Trotter and Roberts } \\
(2006)\end{array}$ \\
\hline \multirow[t]{2}{*}{ Academic leadership } & Demography & Walters (2003) \\
\hline & Nationality and age & Wingate (2007) \\
\hline
\end{tabular}


growth that lie in the unnamed and often ill-defined periods of change that characterise a student's university journey (Cross 1999).

When students commence their university education, they experience ontological shifts and identity transformations that may be akin to 'passing through a portal' and an 'opening up of a new and inaccessible way of thinking about something' (Meyer and Land 2005). Threshold Concepts, as defined by Meyer and Land (2003) are 'threshold' because they have features that are transformative, irreversible, integrative, bounded, potentially troublesome, discursive and reconstitutive. We acknowledge that there are many threshold concepts that come into play when becoming a student, including those relating to language, knowledge creation, theories, frameworks, writing, creativity and many more. We focus specifically here on aspects of the liminal space experienced by those who are learning to be a student, rather than identifying the specific threshold concepts themselves. Once a student registers at a university and begins a specific programme of study, there are multiple thresholds and transitions that students must negotiate in order to successfully complete their university journey within the particular programme. We consider what happens when students at all levels, across all programmes, are positioned in a higher education transitional space that requires the crossing of interwoven and multilayered thresholds.

For us, the theory of Threshold Concepts and Liminality (Meyer and Land 2003) captures the processes of a university journey, the pivotal stage-like trajectories ${ }^{4}$ of a university experience. Liminality reflects the transitions (positive and negative, smooth and choppy) that transform old to new being and learning along the student journey. Liminality helps us better comprehend the complex and multi layered nature of a university experience; it helps to understand and support transitions or 'transformed internal view of subject matter, subject landscape ... [and] world view' (Meyer and Land 2003, p. 1). In this paper, we aim to capture and qualify the transitional process characterised by liminality and explore its potential to influence practice for all stakeholders within higher education. This area of study has previously received little attention in a European student experience context. We draw on empirical data collected through an institution-wide student experience survey (SES) conducted at University College, Cork (UCC). The UCC SES aims to capture 'close-up' expectations, perceptions, hopes and aspirations of students at all stages and at all levels of the student journey.

\section{Research Design and Methodology}

The facilitation of a high quality student experience has been a focus of strategic planning and operational delivery at UCC for a number of years. This became visible within the earlier UCC Strategic Plan 2008-2012 where one of the strategic

\footnotetext{
${ }^{4}$ Akin to 'rites of passage'.
} 
goals was 'Improving the Student Experience'. As part of this activity, a Technical Working Group was tasked with describing and measuring the UCC Student Experience through the design and implementation of the UCC SES. To this end, under- and post-graduates, recruited from broad but non-exclusive categories, were randomly selected and invited to attend a focus group discussion. The focus group research served as the basis for the development of a survey instrument designed to measure the student experience (Kitzinger 1995; Millward 2006). A student experience survey of all registered students of UCC was developed under the direction of the then Vice-President for the Student Experience and the Vice-President for Teaching and Learning. A series of focus groups elicited student views and aided the technical working group to construct a University-wide questionnaire. The UCC Student Experience Survey (UCC SES) was first administered in 2009 and biennially thereafter. This paper is a discourse analysis of unique and previously undocumented primary questionnaire material harvested from the university Student Experience Survey (SES) (UCC, SES 2009, 2011, 2013). In addition, we examine and analyse recent interview data generated from a new study on student experience, 'Facilitating a High Quality Student Experience: finessing approaches (FHQSE)' which aims to capture 'close-up' expectations, perceptions, hopes and aspirations of a small group of incoming students at UCC. Throughout this paper, we draw on quotes from the survey material.

An inductive approach for analysis of the qualitative and quantitative data was adopted, beginning with open coding of the raw textual data into themes and categories (Strauss and Corbin 1990). Complex themes and categories then emerged and formed the initial framework of analysis. Clear links between the underlying structure of student experiences and the findings derived from the analysis and re-analysis of raw data were established. Finally, aspects of the Threshold Concept/Liminality framework that are evident and grounded in the raw data were explored. Like others, we found this a relevant and highly applicable model (Backett and Davison 1995; Meyer and Land 2006; Stolee et al. 1999; Turner 1969). The approach provides a lens through which to further explore and develop institutional approaches and sector-wide best practice that facilitates and supports a high quality student experience. At the heart of the approach is a desire to link and further develop theoretical frameworks to practice in today's universities. The objectives of this paper are to generate perspectives on how students deal with the subjective university experience: the enactment, the expectations, transitions, turning points, change and challenges. We analyze the notion of moving towards and through liminal or 'stuck' places. Whilst we acknowledge the unsettling nature of liminality for some students, we also appreciate the transformative and emergent nature of the liminal space. Our discussion is followed by an examination of the ways in which research has informed policy making at an institutional level, as evidenced by the implementation of strategies to facilitate student progression through what could be described as 'stuck' spaces. 


\section{Results and Discussion}

In the context of research on student experience, many of the findings are not unique to UCC or to Universities in Ireland, but reflect perennial issues in the university student experience. Empirical findings yielded three main themes that specifically frame this paper and each theme will be considered in turn.

(i) Liminality, Threshold Concepts and Student Experience

Liminal space or liminality refers to the period of transformation that students undergo or are challenged by. Liminality is the transition from old to new being (Meyer and Land 2005). The British Cultural Anthropologist, Victor Turner [1920-1983] defined liminality as the in-between time and place in the process of transformation (Turner 1969). Here we explore liminality in the student experience within a threshold concept framework that transcends disciplinary boundaries.

Liminality represents a core threshold concept. Meyer and Land discuss threshold concepts as portals, or ways of understanding. We concur with Meyer and Land (2005) that liminal portals have six distinctive yet fluid characteristics and constitute the overall student experience. They appear to be:

- Irreversible, unlikely to be unlearned (Meyer and Land 2005).

Stimulating learning environment, resources to allow effective academic practice (First year male student, CAO Entry, College of Medicine and Health, 2013).

- Bounded and potentially troublesome (Meyer and Land 2005; Cartensen and Bernhard 2007).

Having to do it for yourself (UG, 2009).

- Discursive, drawing on new and empowering forms of expression (Meyer and Land 2005).

The UCC campus is state of the art, the library facilities and the gym are state of the art and a pleasure to be in (First year female student, CAO Entry, College of Medicine and Health, 2013).

- Integrative, exposing the previously hidden, inter-relatedness of something (Meyer and Land 2005).

The many free facilities it provides, that are of excellent qualities

(First year female, Non EU Entry, College of Arts, Celtic Studies and Social Sciences, 2013).

- Reconstitutive, a required and new understanding (Meyer and Land 2005).

The best thing about UCC is the Brookfield campus for health science, very well equipped for lectures, tutorials and clinical skills and also the Mardyke arena facilities, free classes, lots of equipment; it really encourages you to avail of the services and live a healthier life

(First year female student, Graduate Entry to Medicine, College of Medicine and Health, 2013). 
- Transformative, 'occasioning a significant shift in the perception of the subject' (Meyer and Land 2005).

Learn a lot here, both in academic and life (Fourth year male student, CAO Entry, College of Business and Law, 2014).

The theory of threshold concepts and liminality applies to real life student experience. We see examples of students moving towards and through liminal spaces in terms of challenge, negotiation, growth, learning and re-authorship. The student journey does not represent a 'simple passage in learning from 'easy' to 'difficult', rather it 'often involves messy journeys back, forth...' (Cousin 2008). We therefore focus here on the multidimensional nature of threshold concepts in a student journey, and illustrate that threshold concepts are more than mastery of conceptual concepts. These offer a means of understanding the challenges and interventions required for successfully passing toward and through liminal spaces, and provide a new lens through which those charged with facilitating a high quality student experience can frame their work.

(ii) Student Transitions: getting stuck and opening up Getting Stuck

'Getting stuck' occurs across all disciplinary contexts. The university journey is both cognitive and deeply embodied. The very physical experience of walking into a lecture theatre and embodying student identity for the first time is powerful. Our experience working with and speaking to students about their first days at university (September 2014) attests to their acutely felt embodied experience of taking on and trying out the 'self-as-university-student' identity. Emotion in this context is used 'to refer to an interpretive experience of how one feels, as this experience is embedded in a particular cultural context and its social codes' (Zembylas 2007). Emotion is a social, rather than a psychological construct. Embodiment is 'a linked, hybrid field of flesh and accompanying objects, rather than a series of individual bodies, intersubjectively linked ... [providing] new means of linkage ... (Thrift 2008: 276).

Students are thought to acquire 'a new status and identity' (Meyer and Land 2005, p. 376).

The students in our study spoke about particular transitional realities of university life, 'freedom and flexibility' (UG, Int., 2009) and 'Moving out of home and gaining independence' (First year female student, CAO Entry, College of Science, Engineering and Food Science, UCC, 2013).

In such cases, the rapid movement toward the particular realities of student identity are irreversible and unlikely to be unlearned. A previous identity within the secondary school community and previous ways of being and knowing are unreachable. For some, the loss of the old experience is deeply affective.

In comparison to secondary school I feel lost. Lecturers don't know you; you are simply a number (2013) 
The 'betwixt and between' spaces, where the student 'is naked of self-neither fully in one category or another' (Meyer and Land 2005), is characteristic of this particular state of liminality. The liminal space is powerfully affective. Affect 'is not simply emotion, nor is it reducible to the affections or perceptions of an individual subject' (Thrift 2008: 116). The liminal space discharges intensities, sensations and energies that are beyond 'the inner world or interiority of the human subject' (Zembylas 2007).

The unsettling nature of liminality shapes the individual student experience and the ability or inability to form the practice of university communities. Potential troublesome and bounded features of the student experience at UCC are implicit in the following comments:

- Lecturers sometimes feel distant from the students (2013).

- I have been disappointed by some of the lecturers (2013).

- My department does not focus on the work of the students, but rather their personal research (2013).

- Some lecturers seem uninterested in students' progress (2013).

- The gaps between lectures during the day. I would rather all my lectures were in the morning from 9 til 2 or 3 or in the afternoons all together (2013).

- A lot of the schools/departments are quite spread out from each other, which means students may miss out on part of their lecture while travelling from a building on one side of campus to a building on the other side of campus where their next lecture is held (2013).

- The isolation of satellite campuses (2013).

- Haven't really met a lot of new people since going to college (2013).

- I'm doing arts and I found it hard to integrate socially in such large groups (2013).

The troublesome and bounded nature of the student experience is rooted within a specific community of practice (Wenger 1998). Aspects of student experiences align with Wenger's notion of bounded 'communities of practice' (1998) and the perception that the lecturer or other students are more expert than themselves (2014 interview data). The commencing students need to find their voice and confidence in the academic setting. Liminality for these students represents portals on legitimate peripheral participation, rather than full participation in a safe cultural environment (Lave and Wenger 1991). The potential for students to experience fear and concern regarding risk of academic failure and disappointment in commencing students is a clear 'take out message' for academics. It offers the potential to maximise positive impact on stakeholder issues, concerns and anxieties at an early stage of the student journey.

In other instances, the troublesomeness is linked to language and lecture delivery. Specific discourses have developed within disciplines to represent particular ways of seeing and thinking.

The First Year group felt that having lecture notes posted on Blackboard before lectures were delivered would be beneficial (First Years, Mature Students, 2009) 
They felt some of the theory they covered in their courses was not relevant to the world of work. It was also felt by the International group that it was not positive that international law students often had to take modules on the Irish legal system (Intermediate Years, International Students, 2009)

These discourses distinguish specific communities of practice and practices that are less familiar to students who are peripheral to them.

Emotion is an intricate part of the university experience of transfiguration and often there is a fear of losing part of a previously comfortable self. Our task as university educators is to acknowledge such powerful and affective liminal states, and help students respond and transverse dissatisfaction to stimulate transfiguration and acceptance of extended discourses. In this way, challenge and discomfort has the potential to become a positive learning and developmental experience.

According to William Perry: "Each of the upheavals of cognitive growth threatens the balance between vitality and depression, hope and despair. It may be a great joy to discover a new and more complex way of thinking and seeing; but yesterday one thought in simpler ways... it appears that it takes a little time for the guts to catch up with such leaps of the mind" (Perry 1981, p. 108).

It takes time and support for 'emotions to catch up with mind' (Meyer et al. 2010: 7). Similarly, Ellsworth (1989) has warned against tendencies in pedagogy towards the disembodiment and neglect of social and affective dimensions of the learning experience.

Ellsworth advises educators to cultivate: “... a third ear that listens not for what a student knows (discrete packages of knowledge) but for the terms that shape a student's knowledge, her not knowing, her forgetting, her circles of stuck places and resistances" (Ellsworth 1997: 71).

Deconstruction of emotional student experiences could be used to foreground the 'limits, the misfiring of [university] pedagogy' (Lather and Ellsworth 1996, p. 1). The 'privileging of containment over excess, thought over affect, structure over speed, linear causality over complexity, and intention over aggregate capacities' (Lather 1998: 497) obscures recognition of 'stuck places'. In 2011, 33 \% of [UCC] research postgraduate students found their research experience to be moderately to very much lonely, $40 \%$ found it to be slightly to somewhat lonely and $27 \%$ found it not to be lonely (UCC, SES 2011).

$38 \%$ of [UCC] research postgraduate students found their research experience to be moderately to very much frustrating, $51 \%$ found it to be slightly to somewhat frustrating and $3 \%$ found it not to be frustrating (UCC, SES 2011).

And in 2013, $28 \%$ of [UCC] research postgraduate students found their research experience to be moderately to very much lonely, $42 \%$ found it to be slightly to somewhat lonely and $30 \%$ found it not to be lonely (UCC, SES 2013).

$37 \%$ of [UCC] research postgraduate students found their research experience to be moderately to very much frustrating, $52 \%$ found it to be slightly to somewhat frustrating and $11 \%$ found it not to be frustrating (UCC, SES 2013).

The above data illustrate that some PG research students at UCC (as is the case elsewhere) experienced 'stuck places' of loneliness and frustration in 2011 and 
2013 (see also Enríquez 2014). Additional 'stuck places' were noted in 2013 data for a small number of UG and PG students: "It's difficult to manage the workload and family life ..."(2013);"...some of the staff can be dismissive at times..." (2013); "It is quite confusing, and sometimes I feel like there is not enough support for visiting students..." (2013); "Incredibly heavy workload that makes it impossible to fully engage with the subjects and to do independent learning" (2013).

These students find difficulty in playing 'the underlying game' (Perkins 1997). They may not appreciate the ever-increasing complexity of university challenges. The result of 'getting stuck' may be enabling or disabling in terms of its impact on learning and experience (see Savin-Baden 2008; Savin-Baden and Tombs 2010). Getting stuck powerfully 'registers on the body' and 'affects' bodies' (Zembylas 2007).

\subsection{Opening Up and Jumping Off a Cliff}

Our analysis suggests that the university experience is shaped by multiple layers of interacting context (Palmer and Marra 2008). Within UCC's setting, it would appear that, on the part of the student, there may be obstacles to happily achieving a new student identity, occasioning entry into 'stuck places'. There may also be a form of 'mimicry' where thinking and acting are tacit or ritualised. In all cases, discursive, integrative and reconstitutive transitions or 'change of skins' characterise the learning process (Nin 1971, p. 26).

The university experience is shifting, affective, embodied and emotional. Transforming student epistemologies, liberating students from that in which they were embedded, 'making what was subject into object' so that they can 'have it', rather than 'be had' by it, is according to Kegan 'the most powerful way I know to conceptualise the growth of mind' (Kegan 1994). Undergraduate and post graduate students in our study acknowledged that their university experience was discursive, integrative and reconstitutive: "Great learning experience"; "Opened your mind"; "Allowed them to make more informed decisions about the future"; "Different person at the end of college"; "Increased overall confidence"; "Preparation for the future"; "Always stand to you" (UCC Student 2009).

Here, education is recognised as representing more than academic and professional outcomes. There is an openness to the nature of the student experience and the potential meaning making which weaves epistemological, intrapersonal and interpersonal threads.

Further, learning is about 'entrance into .... a community of people who share that way of thinking and practising' (Davies, 2006 in Meyer and Land 2006, p. 71). A fourth year female student told us: "There is a large community of academic people in this university all with the common interest of furthering our learning in our chosen field. It is a very reassuring notion that you are surrounded by many like minded people with the same objective as you." 
Grasping the university experience is never purely a cognitive shift; it also involves a repositioning of subjectivity. Learner identity is increasingly complex and inter related with thinking, acting and language. University culture is shaped and shaping: 'It is through and by language and discursive practices [that] selfhoods are constructed, identities are forged, and social processes are enacted' (Gonzalez 1999, p. 433).

University reality is a constant process of negotiation and transitions. Entering a transitional space, according to Kegan, feels 'much like going off a cliff' (1994, p. 11). Transitions characterise every university student experience. Students who are open to the possibility of transformation and willing to accommodate alternative expressions of meaning and extended discourses may experience: “... a deep, structural shift in the basic premises of thought, feelings and actions. It is a shift of consciousness that dramatically and irreversibly alters our way of being in the world" (O'Sullivan 2003).

'Opening up' within a liminal space represents a rite of passage or a point “... a deep, structural shift in the basic premises of thought, feelings and actions. It is a shift of consciousness that dramatically and irreversibly alters our way of being in the world" (O'Sullivan 2003; van Gennep 1960). Opening up reflects a dawning, an 'Aha' moment, which unexpectedly lights up the way (Meyer and Land 2003). The experience of crossing liminal terrains can range from turbulent to smooth. Varied experiences of liminality suggest that conceptual and ontological dimensions characterise the liminal space (Land 2012).

Threshold concepts define powerful transformative stages along an 'excursive' student journey - a journey that will commence with an intended outcome but may have a revised passage and ultimate destination. Threshold concepts align with a student focused and 'participative' approach to learning (Sfard 1998). A lack of understanding of threshold concepts confines learners to liminal and peripheral spheres (Lave and Wenger 1991). When students pass through the portals seamlessly, they advance learning and engage 'authentically' in the practices of the community (Meyer and Land 2003; Sfard 1998). The role of university staff (including academics and professional service staff) in supporting a smooth passage through a number of portals merits further exploration.

(iii) University Transitions: leaps of change in the name of quality

The innovations that have been instigated at UCC to date are conceived as helping facilitate a high quality student experience and, centre on cultivating relationships and benefits for all stakeholders involved in the educational journey. The approach developed to help students negotiate the higher educational terrain is a holistic one, with the personal and professional development of students throughout the student journey at its core. Innovations include. 
Table 2 SES 2013 overall student satisfaction scores

\begin{tabular}{l|l|l|l}
\hline \multicolumn{2}{l|}{ Undergraduates } & Postgraduate taught & $\begin{array}{l}\text { Postgraduate } \\
\text { research }\end{array}$ \\
\hline $\begin{array}{l}\text { Satisfaction with } \\
\text { Overall }\end{array}$ & $\begin{array}{l}\text { Almost nine in } 10 \\
\text { satisfied with overall } \\
\text { Experience } 2013\end{array}$ & $\begin{array}{l}\text { Four in five satisfied } \\
\text { with their overall } \\
\text { experience }\end{array}$ & $\begin{array}{l}\text { Four in five satisfied } \\
\text { with their overall } \\
\text { experience }\end{array}$ \\
\hline
\end{tabular}

Student stakeholders specifically noted their level of satisfaction with the overall university student experience in 2009, 2011 and 2013, across four broad areas (UCC, SES 2013)

\subsection{Developing Approaches to Hearing the Student Voice}

The student experience survey which has generated the data set for the research reported in this paper was introduced and has been developed further, in order to listen to the student voice. The biennial Student Experience Survey (SES), with a focus on a broad concept of the student experience, has provided feedback relevant to a number of strategically important areas since its inception in 2009. In the 2009 survey there was a $73 \%$ satisfaction with university life, increasing to $78 \%$ for Broad Satisfaction. ${ }^{5}$ The outcomes of the most recent (UCC, SES 2013) SES open to all registered students, and which incorporated a number of validated scales, were very positive, whilst leaving room for continued improvement (Table 2):

- Supporting success

High standard of learning, excellent lecturers who put in time and effort (Second Year Female, 2013).

- Health and Well-Being

The atmosphere is really great. Campus is refreshing and full of nice people. The lecturers are always willing to give helps (sic) ns (sic) advice and for the most part are very understanding of any personal problems you may be having (Female, 2nd Year, 2013).

- Employability and Further Study

Learn a lot here, both in academic and life (Fourth Year Male, 2014).

The opportunity to access a level of education that you desire and the hope that it will result in a prosperous career (Third Year, Female Student, 2013).

- Student Life: facilitating engagement with student life

Feeling as if you're part of a community of people who are all motivated to get the best out (sic) their time at Uni, in both academic and social aspect. We work hard, party harder and then struggle through labs the next day (UCC Student, 2013)

\footnotetext{
${ }^{5}$ Total number of respondents, 3015 .
} 
The SES is not the only survey relating to the student experience. A sub-group of the UCC Academic Council Teaching and Learning Committee prepares and conducts the university module survey. In addition, the new Irish Survey of Student Engagement (ISSE) runs in February/March of each year, having been piloted in 2013. Exchange and interaction of ideas via student surveys ensures student/stakeholder engagement around emerging issues. The results provide for assessment of progress and highlight areas that require further improvement. The challenge is the presence of conflicting stakeholder demands and concerns. In UCC, the ongoing development of the Student Experience Office is one example of an organizational, functional and visible response to stakeholder issues and needs.

A leading action for achievement for 2017 is to pursue excellence in teaching and learning by listening to the student voice,

High-quality research led teaching is at the core of our mission ...We will continually improve the quality of the student experience by acting on student feedback and on recommendations for quality improvement. Improved supports for student learning, personal and employability skills development will be provided through the development of our state-of-the-art 'hub' building. (Strategic Plan for the student experience 2013-2017: 15).

\subsection{Creating a Student Experience Office}

A core innovation at UCC has been the creation of a Student Experience Office (SEO) in 2007/8. The SEO leads and coordinates the strategic development and direction of policy and practice related to the Student Experience in a range of functions and activities. It strives to facilitate a world class student experience through which all students are empowered and supported to achieve their goals.

The SEO aims to ensure that every student develops not only academically, but also personally within an attractive and supportive environment with an increasingly diverse and international student population. In line with strategic aims of the University and of the SEO, thematic strategies have been implemented that hold the potential to facilitate progression through liminal spaces encountered on a student journey. The areas of focus include

- Office wide/service wide developments

- Contributing to Outreach and Transition into University

- Supporting Student Retention, Progression and Success

- Supporting Student Health and Wellbeing

- Facilitating Engagement in Student Life

- Supporting Transition to Work and Further Study. 


\subsection{Promoting a Holistic Student Experience}

The current Strategic Plan (UCC, 2013-2017) for Student Experience aims to deliver "... strong student focused support services and activities ...based on the three phases of the student lifecycle - transition... time in ... and support for the transition out of UCC...." (UCC, Strategic Plan 2013-2017: 17).

The unique focus on successful transition into the university has seen the development of a wide-ranging orientation programme by the First Year Experience Coordinator (this post was introduced in 2007), supported by a comprehensive peer support programme (established in 2009) and through well-coordinated cross university efforts within all academic and professional service units. A student's time in university is supported in multiple ways, with a key focus on supporting retention, progression and success. This includes specific post entry support for particular cohorts of students linked to access (namely disabled students, mature students and socio economically disadvantage students), academic tutorials linked to, for example, the development of writing skills and referencing; the provision of online support; dedicated support for international students and the on-going interaction of peer support leaders in a variety of ways. The university proactively adopts a philosophy of continuous improvement; for example, plans are currently being finalised to co-locate a number of professional services with teaching and learning and student led initiatives within one 'student hub', and the university has recently increased support for 'talented' students. The transition out of university to work and/or further study is equally significant. The careers service provides traditional one to one advice and guidance, and has also developed comprehensive work experience, volunteering and internship opportunities for all undergraduate students. As with many universities, the first employment destination of graduates is tracked 6 months from graduation, and academic programmes are supported to include employability related content within their curricula.

The University has placed a high priority on developing comprehensive programmes and structures in the areas of health and wellbeing and engagement in student life, linked to the interwoven objectives of supporting student success and employability. The university is currently working towards health promoting university status, is in the vanguard of developing actions to reduce harmful alcohol consumption amongst students and has produced ground breaking training materials that highlight the role of front line staff in supporting students in distress. Student involvement in sports clubs, student led societies, community volunteering and leadership activities is also encouraged and facilitated by university administrative staff. Whilst increasing student participation in the full breadth of student life is challenging in the face of increased diversification of the student body and a parallel increase in student financial pressure, such dimensions of the student experience remain a key component of the aspired-to high quality experience. 


\subsection{Developing New Strategies to Facilitate Improved Student Progression Through Liminal Spaces}

Following a quality review (QR) in 2014, the SEO at UCC continues to develop and refine its approach to facilitating a world class student experience. ${ }^{6}$ The QR process helped to identify a number of thematic and cross service opportunities and projects which are being designed to improved outcomes for students in a number of areas. Projects to be developed will include:

- Increase opportunities for the student voice to inform development of policy and practice

- Establish opportunities for student experience staff to attend relevant College/School-level committees and groups

- Develop research and evaluation projects and disseminate outcomes nationally and internationally

- Develop systems and databases to support the student experience across all services

- Support students to set and reflect on personal and professional development goals throughout the student experience

- Develop clearer messages to students at different points in the student journey.

A shift towards the adoption of project methodology across thematic areas of the student experience is taking place to account for the crossing, by students, of interwoven and multilayered thresholds. Within this context, the delivery of support within somewhat isolated and vertical service units is problematic, and it is thought that further value can be added by working in cross cutting ways. In this way, our theoretical understanding is supporting on-going practical application within student support and professional service structures.

\section{Conclusions}

To date, the majority of research into threshold concepts and liminality has focused on their identification in various disciplines and their characteristics in relation to expert discourse (see Burchmore et al. 2007). The characteristics of threshold concepts and liminality adopted here help us to define critical points in the broader student experience - that of passing through a new threshold. We challenge academics and administrators to put in place and further develop more innovative and nuanced support structures, and equip students with 'threshold capital' that responds to such changes and that helps them become unstuck, to open up and

\footnotetext{
${ }^{6}$ The internal QR was conducted by a peer review panel composed of internal and external reviewers, in line with a quality framework for all departments at UCC.
} 
move along the spectrum of liminality (Land 2012). There are many ways in which this is and can be best achieved.

We suggest that threshold concepts and liminality may provide a framework for developing understanding of how best to initiate innovative pathways for students throughout their university journey. These concepts provide a novel frame to enable explanatory insight into the student experience within liminal spaces, and renders the space (and the student experience within) more open to analysis. Rather than thinking purely about the outcomes of a university journey, for example through degree classifications and graduate employment rates, threshold concepts and liminality provide a point of focus for innovations in learning across and within subjects and discipline boundaries. The threshold concepts/liminality framework offer the potential to be both epistemological and ontological - to be part of the macro university framework to stimulate activities, reflection and transitions that could generate 'high quality' (Elliott 2007).

Threshold concepts and liminality provide a lens through which to further explore and develop institutional and sector wide approaches to quality within the student experience. Research is required to better understand the experiences of specific cohorts at a micro level. We will continue to endeavour to capture 'close-up' expectations, perceptions, hopes and aspirations of a small group of university students. Most importantly, in support of professional colleagues working to support the student experience, we aim to explore specifically the liminal stages that students in higher education pass through, and the effect of specific structures or interventions that may smooth transitions. For example, we will enhance understanding by further administering the use of exit surveys for all students who withdraw from higher education and identify other points of transition where data can be collected.

Our research will add richness to the existing data, extending it to examine student negotiation of liminality and to reflect on innovative practices that enable transformative progression through liminal spaces. Our research deals specifically with the threshold concepts and liminality that form part of the university experience. We contest that this approach holds significant potential for informing practice through which the student experience can be enriched and through which institutions can best organise resources to achieve strategic aims.

Open Access This chapter is distributed under the terms of the Creative Commons Attribution Noncommercial License, which permits any noncommercial use, distribution, and reproduction in any medium, provided the original author(s) and source are credited.

\section{References}

Altbach, P. G. (2002). Knowledge and education as international commodities. International Higher Education, 28, 2-5.

Altbach, P. G. (2004). Globalization and the university: Myths and realities in an unequal world. In National Education Association (Ed.), The NEA 2005 almanac of higher education (pp. 6374). Washington, D.C.: National Education Association. 
Altbach, P. G., \& Knight, J. (2007). The internationalization of higher education: Motivations and realities. Journal of Studies in International Education, 11(3-4), 290-305.

Backett, K. C., \& Davison, C. (1995). Lifecourse and lifestyle: the social and cultural location of health behaviours. Social Science and Medicine, 40(5), 629-638.

Bekhradnia, B., Whitnall, C., \& Sastry, T. (2006). The academic experience of students in English Universities. London: Higher Education Policy Institute.

Bent, M. (2008). Perceptions of Information Literacy in the Transition to Higher Education (National Teaching Fellow Project Report) [online]. Newcastle upon Tyne: Newcastle University. Available from: http://eprint.ncl.ac.uk/pub_details2.aspx?pub_id=55850

Biggs, J., \& Tang, C. (2011). Teaching for quality learning at University. Maidenhead: McGraw-Hill/Open University Press.

Booth, A. (2009). Worlds in collision: university tutor and student perspectives on the transition to degree level History Retrieved from http://www.history.ac.uk/resources/History-in-britisheducation/second-conference/booth-paper

Bordonaro, K., \& Richardson, G. (2004). Scaffolding and reflection in course-integrated library instruction. The Journal of Academic Librarianship, 30(5), 391-401.

Brinkwork, R., McCann, B., Matthews, C., \& Nordstrom, K. (2009). First year expectations and experiences: student and teacher perspectives'. Higher Education, 58(2), 157-173.

Burchmore, H., Irvine, N., \& Carmichael, P. (2007). Threshold concepts: a review of related literature. Cambridge: Centre for Applied Research in Educational Technologies, University of Cambridge.

Cartensen, A. K., \& Bernhard, J. (2007). In R. Land, J. H. F. Meyer, \& J. Smith (Eds.), Threshold concepts within the disciplines. Rotterdam: Sense Publishers.

Chrisite, H., Tett, L., Cree, V., Housell, J., \& McCume, V. (2008). A real rollercoaster of confidence and emotion: learning to be a university student. Studies in Higher Education, 33 (5), 567-581.

Colvin, J. (2007). Peer tutoring and social dynamics in higher education. Mentoring and Tutoring, $15(2), 165-181$.

Cook, A., \& Leckey, J. (1999). Do expectations meet reality? A survey of changes in first year student opinion. Journal of Further and Higher Education, 23U(2), 157-171.

Cousin, G. (2008). Threshold Concepts: Old Wine in New Bottles or New Forms of Transactional Inquiry. In R. Land, J. H. F. Meyer, \& J. Smith (Eds.), Threshold concepts within the disciplines. Rotterdam: Sense Publishers.

Crabtree, H., Roberts, C., \& Tyler, C. (2007). Understanding the problems of transition into higher education.

Cross, P. (1999). What do we know about students learning and how do we know it? Innovative Higher Education, 23(4), 255-270.

Elliott, J. (2007). Assessing the quality of action research. Research Papers in Education, 22(2), 229-246.

Ellsworth, E. (1989). Why doesn't this feel empowering? Working through the repressive myths of critical pedagogy. Harvard Educational Review, 59(3), 297-324.

Ellsworth, E. (1997). Teaching positions: difference pedagogy and the power of address. New York: Teachers College Press.

Enríquez, L. (2014). University Outreach; a line of work for enhancing students' academic identity within distance education and open universities. Paper presented at the Proceedings of World Conference on Educational Multimedia, Hypermedia and Telecommunications, Chesapeake.

Finegan, F., Merrill, B., \& Thunborg, C. (2014). Student voices on inequalities in european higher education: challenges for theory, policy and practice in a time of change. Oxon: Routlege.

Gonzalez, N. (1999). What will we do when culture does not exist anymore? Anthropology and Education Quarterly, 30, 431-435.

Harvey, L., Drew, S., \& Smith, M. (2006). The First Year Experience: a Review of the Literature for the Higher Education Academy. http://www.heacademy.ac.uk/assets/York/documents/ ourwork/research/literature_reviews/first_year_experience_exec_summary.pdf 
Huet, I., Baptista, A.V., Costa, N., Jenkins, A., \& Abelha, M. (2009). Evaluation of Undergraduate Students' Involvement in Research Projects, 2009).

Hussey, T., \& Smith, P. (2010). Transitions in HE. Innovations in Education and Teaching International, 47(2), 155-164.

Hultberg, J., Plos, K. Hendry, G.D., \& Kjellgren, K.I. (2008). Scaffolding students' transition to higher education: parallel introductory courses for students and teachers. Journal of Further and Higher Education, 32, 47-57.

Irish Department of Education and Skills Higher Education System Performance Framework, 2014-2016. European Association for Quality Assurance in Higher Education. 2009.

Kegan, R. (1994). In over our heads: the mental demands of modern life. Cambridge, MA: Harvard University Press.

Kember, D. (2001). Beliefs about Knowledge and the Process of Teaching and Learning as a Factor in Adjusting to Study in Higher Education, Studies in Higher Education, 26 (2). http:// www.tandfonline.com/doi/abs/10.1080/03075070120052116

Kitzinger, J. (1995). Introducing focus groups. British Medical Journal, 311, 299-302.

Land, R. (2012, 28-29 June 2012). A Closer Look at Liminality: Incorrigibles and Threshold Capital Paper presented at the Keynote Presentation, Fourth Bienniel Conference on Threshold Concepts: From personal practice to communities of practice, Trinity College, Dublin.

Lather, P. (1998). Critical pedagogy and its complicities: a praxis of stuck places. Educational Theory, 48(4), 487-498.

Lather, P., \& Ellsworth, E. (1996). Introduction: situated pedagogies. Theory into Practice, 35(2).

Lave, J., \& Wenger, E. (1991). Situated learning. Legitimate peripheral participation. Cambridge: University of Cambridge Press.

Leap, T., \& Loughry, M. L. (2004). The stakeholder-friendly firm. Business Horizons, 47(2), 27-32.

Leese, M. (2010). Bridging the gap: supporting student transitions into higher education. Journal of Further and Higher Education, 34(2), 239-251.

Loukkola, T., \& Zhang, T. (2010). Examining quality culture part 1: quality assurance processes at higher education institutions. Brussels: European University Association.

Lumsden, E., McBryde-Wilding, H., \& Rose, H. (2010). Collaborative practice in enhancing the first year student experience in higher education. Enhancing the Learner Experience in Higher Education, 2(1), 12-24.

Mayhew, M., Vanderlinden, K., \& Kyung, K. E. (2010). A multi-level assessment of the impact of orientation programs on student learning. Research in Higher Education, 51(4), 320-345.

Meyer, J. H. F., \& Land, R. (2003). Threshold concepts and troublesome knowledge: linkages to ways of thinking and practicing within the disciplines. In C. Rust (Ed.), Improving student learning: improving student learning theory and practice-10 years on. Oxford: Oxford Centre for Staff and Learning Development.

Meyer, J. H. F., \& Land, R. (2005). Threshold concepts and troublesome knowledge (2): epistemological considerations and a conceptual framework for teaching and learning. Higher Education, 49, 373-388.

Meyer, J. H. F., \& Land, R. (2006). Overcoming barriers to student understanding. Oxon: Routledge.

Millward, L. J. (2006). Focus groups. In G. M. Breakwell, S. Hammond, C. Fife-Schaw, \& J. A. Smith (Eds.), Research methods in psychology. London: Sage.

Nin, A. (1971). The diary of Anais Nin 1944-1947. London: Harcourt.

O'Sullivan, E. (2003). Bringing a perspective of transformative learning to globalized consumption. International Journal of Consumer Studies, 27(4), 326-330.

Palmer, B., \& Marra, R. M. (2008). Individual domain-specific epistemologies: implications for educational practice. In M. S. Khine (Ed.), Knowing, knowledge and beliefs: epistemological studies across diverse cultures. Dordrecht: Springer.

Perkins, D. (1997). Epistemic games. Journal of Educational Research, 27(1), 49-61.

Perry, W. G. (1981). Cognitive and Ethical Growth: The Making of Meaning. In A. W. Chickering (Ed.), The modern american college: responding to the new realities of diverse students and a changing society. San Francisco: Jossey-Bass. 
Reason, R., Terinenzini, P., \& Domingo, R. (2006). First things first: developing academic competence in the first year of college. Research in Higher Education, 47(2), 149-175.

Rivza, B., \& Teichler, U. (2007). The changing role of student mobility. Higher Education Policy, 20, 457-475.

Savin-Baden, M. (2008). Liquid learning and troublesome spaces: journeys from the threshold? In R. Land, J. Meyer, \& J. Smith (Eds.), Threshold concepts within the disciplines. Rotterdam: Sense Publishers.

Savin-Baden, M., \& Tombs. (2010). Student Experiences of Learning in Immersive Virtual Worlds. In R. Sharpe, H. Beetham, \& S. d. Freitas (Eds.), Listening to Learners in the Digital Age. London: Routledge.

Sfard, A. (1998). On two metaphors for learning and the dangers of choosing just one. Educational Researcher, 27(3), 4-13.

Stolee, P., Zaza, C., Pedlar, A., \& Myers, A. M. (1999). Clinical experience with goal attainment scaling in geriatric care. Journal of Aging and Health, 11(1), 96-124.

Storrs, D., Putsche, L., \& Taylor, A. (2008). Mentoring expectations and realities: an analysis of metaphorical thinking among female undergraduate Protégés and Their Mentors in a University Mentoring Programme. Mentoring and Tutoring: Partnership in Learning, 16(2), $175-188$.

Strauss, A., \& Corbin, J. (1990). Basics of qualitative research. Newbury Park: Sage.

Thrift, N. (2008). Non-representational theory: space, politics, affect. New York: Routledge.

Trotter, E., \& Roberts, C. A. (2006). Enhancing the early student experience. Higher Education Research and Development, 25(4), 371-386.

Turner, V. (1969). The ritual process: structure and anti-structure. Chicago: Aldine Publishing.

University College Cork, Student Experience Survey (SES) (2009, 2011, 2013).

University College Cork, Strategic Plan, Sustaining Excellence 2013-2017.

van Gennep, A. (1960). The rites of passage. London: Routledge \& Kegan Paul.

Waters, J.L. (2003). 'Satellite Kids' in Vancouver: transnational migration, education and the experiences of lone children. In, Charney, M.W., Yeoh, B.S.A. \& Kiong, T.C. (Eds.), Asian Migrants and Education: The tensions of education in immigrant societies and among migrant groups. Dordrecht: Kluwer Academic Publishers.

Wenger, E. (1998). Communities of practice: learning, meaning and identity. Cambridge: Cambridge University Press.

Wingate, U. (2007). A framework for transition: supporting 'learning to learn' in higher education. Higher Education Quarterly, 61, 391-405.

Wortham, S. (2006). Learning identity: the joint emergence of social identification and academic learning. New York: Cambridge University Press.

Zembylas, M. (2007). Five pedagogies, a thousand possibilities: struggling for hope and transformation in education. Rotterdam/Taipei: Sense Publishers. 